\title{
SOCIAL-REALISM IN THE AZERBAIJANI AND TURKISH NOVELS OF THE EARLY 20TH CENTURY \\ Eshgane Babayeva $^{1}$
}

Abstract: In the 1920s and 1940s, the socialist realism (trend) flow in both Turkish and Azerbaijani literature shows itself in certain degree. Class struggle, conflict between opposing forces, such as master-peasant, intellectual-ignorantsuperstition, has become the main topic of the Turkish and Azerbaijani novels. In both literatures, the subject of village was at the forefront. It is no coincidence that "Homeland Literature" has gained special popularity in Turkish literature in this period. The life, love, joy, sorrow, troubles and pains of ordinary peasants have become the main topic of literature. The story of the urban man, not the peasant, his or her life, feelings and thoughts came to the center of the novel, not the destiny of townsman. However, for a long time, the place in the Turkish novels was chosen only as Istanbul, and the fate of the people of Istanbul was mentioned. In the article, the Turkish and Azerbaijani novels from 1920 to 1930will be comparatively explored and parallels will be emphasized.

Keywords: Azerbaijani and Turkish novel, socialist-realism, rural novel, comparison, conflict.

\section{Introduction}

Socialist-realism is known as the second half of Marxist aesthetics. Some measures agreed in 1934 that the Soviet Writers Union Congress has determined the content of this understanding. Socialist approach to engage wanting to serve the socialist revolution, sought to establish a literary artist. Socialist-realism has also affected the Turkish literature, various issues were discussed socialist literature from the 1930s. These discussions have focused more on the social role of art and artists issues. Turkish writer and critic of the Marxist theoretical information about the inadequate aesthetic issues are

\footnotetext{
${ }^{1} \mathrm{PhD}$ in Philology, Associate professor. Institute of Literature named after Nizami Ganjavi of ANAS/ Azerbaijan,Baku. Email : eshqane@mail.ru. ORCID: https://orcid.org/0000-00024934-4168
} 
discussed in more axis of concept of populism. Turkish authors have interpreted this as socialism facing the public literature.

One of the issues that attracted attention in both Turkish and Azerbaijani novels in the early twentieth century was about rural life. It should be noted that interest in rural life, love and longing for the village began to show itself in poetry. Orkhan Okai, the prominent Turkologist associated the beginning that he called "return to the village, to Anatolia" with the development of pastoral poetry in the literature (Okai O., 1990; 110-115). According to researcher Kenan Akyuz, rapid development of the industry, technology like in the Western world, has brought some problems with itself. Thus, the concept of shelter to the villages and the nature from the big cities emerged in the intellectuals of the Tanzimat era, which at the same time was an expression of the transition to the change of place in literature (Akyüz K., 1979: 18). R. Kaplan linked this issue mainly with the entry of literature into social service (Kaplan R., 1997: 7). By agreeing with this idea of the Turkologist, I would like to note that interest in rural life, turning of the theme of village into the leitmotif of novel was demand of the period, result of a new social-political, economic and literary process. Turkey joined the new literary process. One of the main directions was national character. While following of the process of that period, it is evident that direction towards the village in the plan of thought had begun in the years of Mashrutiyyat (1908-1923), and the ideology "toward the people" of Ziya Gokalp (1876-1924) was of particular importance in this regard. Ziya Gokalp believed that intelligentsia, distinguished people had two goals of directing the to the people:

1) To go toward the people for getting national-spiritual values (to make alive) from the people.

2) To go toward the people to take culture to them. For realizing of these two nuances, in the opinion of Ziya Gokalp, Turkic young people should teach in rural schools to carry the "Western culture, not the Eastern culture or its branch, Ottoman culture" to the village (Gokalp Z., 1970: 47).

Although this process slowed down, it gained momentum and became one of the strategic goals of the new state in the period of Republic. Ataturk stated 
on March 1, 1922 that he was talking about the peasants in the third opening year of the parliament and expressed the value given to them: "Who is Turkey's owner and master? The true owner of Turkey is its peasant. In this case, peasant deserves to live in prosperity, happiness and wealth more than anyone else does" (Atatürk's Speeches And Statements I, 1945: 209).

Therefore, on March 18, 1924, the Rural Law came into effect and a new governance system was formed in the village. On the one hand, the village institutes (1940-1954) opened. Graduates of these institutes have started to express the problems and troubles of the village. This new literature has been called "Anatolian literature". It should be noted that in general, "Anatolia" in Turkish literature has a very new and different meaning. Anatolia - in fact an ideal,not a handful of land. Prof. Alamdar Yalchin notes that it has very important social, literary-cultural and political reasonsgiving this new literature the title of "Anatolia". This novel concept will be called the "Rural novel" for various social reasons in the 1940s. Such concept of novel survived
507

itself until the end of the 1960s (Yalcin A., 2012: 26).

\section{Research Aim}

The main purpose of this article is to investigate the effect of social realism on Turkish and Azerbaijani literature. In this article, the subject of village was investigated in Turkish and Azerbaijani novels of 1920s. Azerbaijani and Turkish novels were compared and similar and different aspects were mentioned. The article is relevant in terms of investigating the AzerbaijaniTurkish village novels comparatively.

\section{Research Methods}

In this article, is investigated social realism in Azerbaijan and Turkish novels (1920-40 years).

The work uses system, structural and comparative methods of research, the method of hermeneutic analysis of the literary text.

\section{Discussion}

The first stories and narratives about the rural life are Ahmed Midhat Efendi's “A Real Story” (1876), "Felicity" (1885), Nazim Nebizade's “Garabibik" (1890), Abubakr Nazim 
Tepeyran's “Little Pasha” (1910), Rafiq Khalid Garay's "Hometown Stories" (1919).

Starting from the 1920 s, the subject of the village turned into a new stage in the creativity of writers such as Y. G. Garaosmanoghlu, B. Cahit, S. Ertem, R. Enis, R. N. Guntekin and others. We can mention the novels of "When the spinning wheels stopped" (Sadri Ertem), "Pitchfork" (Yagub Gadry Garaosmanoghlu), "Yusuf of Kuyucak" (Sabahattin Ali), "Novel of the decade" (Izzet Benice), "Their novel" (Aka Gunduz), "Green Night", "The wren" (Reshad Nuri Guntekin),, "Rural Doctor" (Burhan Cahit Morgaia), "Beat the immortal" (Khalida Adib Adivar), "The child of the Mountain" (O. R. Gokche) and others in this period.

As we have seen, in the same years, theme of the village has a special place in the Azerbaijani novels. The novels of the 1930s included issues such as the struggle for collectivization in the Azerbaijani village, the process of Sovietization and the process of collectivism. Himalay Enveroglu writes about this:

"If the conversation is about in literature of this epoch, but rather the novel, then it should be noted that the revolutionary-historical theme was of particular importance in the literature of the 1920-50s. The writers have tried to justify the source of the way leading to the socialist revolution with the subjects taken from distant and near revolutionary-historical past; they have sought to meet the demands of the socialist realism's creative method that considers the historical philosophy of materialism as the main methodological principle. In the sense of the concept, it was prepared on the basis of Russian literature, direct experience of M. Gorky, Furmanov, Serafimovich, A. Tolstoy, Qlaldkov, Fadeyev and others (Enveroglu, 2008: 139-140). Other sources also find that the ideological, political and literary life of the 1920s and $1930 \mathrm{~s}$ is based on the traditions of Russian literature (Asadullayev, 1970: 65). Commenting on these issues, Himalay Enveroghlu also emphasized that the Azerbaijani novel in the 192030s was put into this political-ideological flow, and it was very difficult to escape from this flow (Enveroglu, 2008: 140). Therefore, the novels such as "Shamo" (first volume-1930), "Downs" (1930), "The World Breaks Out" (1933), 
"Warrior City" (1933), "Flood" (19331935), “Hero" (1937), “Tarlan”(193640), "Haired" (1940-41) and other novels written in 1950s such as "Our Daughters" (1950), “Great Days" (1951), "Flowery" (1951), “Citizen" (1953), "Spring Evenings" (1954-1955), "Separated Roads" (1956), “Great Support" (1957), "Ditch By Willow" (1958), "Village Doctor (1959)", "Journalist Goes To The Village" (1963) reflect these trends. G. Khalilov, the outstanding scientist analyzed some of these works from the point of plotcomposition in his monograph "From The History Of The Development Of Azerbaijani Novel", saying that Abulhasan's "Uphills", Ali Veliyev's "Hero" and Mehdi Husein's "Tarlan" had almost the same plot line, the novels of "Separated roads", "Flowery", "Great support", "Ditch by willow", "Leaves", "Heart friends", "Longing”, "Lowland", etc., dedicated to the collective farm in the 1950-60sare not so different from each other (Khalilov G., 1973: 161). Of course, the main reason for this was that the literature emerged from that period served a single ideology.

In Turkey, in 1923, the Republic was established and the
Republic's literature on new trends emerged. Researcher Metin Chingiz describes this stage as follows: "After the establishment of the Republic, fault of thought brought with the law of "Homeland betrayal", press offenses and penalties with Press law brought in 1931, the official close of associations and parties (after 1938) gives us extensive information about that period" (Chingiz M., 2000: 11-12). At that time, one-party system was dominant, but left-wing flow in literature showed itself. Nazim Hikmet, Sadri Ertem, Faik Baisal, Sabahaddin Ali, Reshad Enis, Aziz Nessin and other representatives of socialist realism were writing works in this subject. When we study this period and socialist-realist writers, we see that they are constantly under pressure, their works censored, and they were sentenced to imprisonment. These issues were reflected in the activity of Nazim Hikmet, where the Azerbaijani reader is well acquainted with him by reading with love. As we know, Nazim Hikmet studied at Moscow University in 19221924 and returned to Turkey where he was sentenced to fifteen years in prison in 1925 for propagating Communist ideology in the "Orag - Chakic" 
(Hammer and sickle) and "Aydinlig" (Clarity) newspapers, in 1927 he secretly fled to the Soviet Union. Let's note that poet came to Baku in 1928. In 1932, N. Hikmat was again sentenced to five years in prison, but was released a year later. The poet was sentenced to 28 years in prison in 1938, he wrote "Human Landscapes", "Letters from Prison", "The Legend of Love" (A. Malikov wrote the ballet called like it) and other works here. In 1950, Nazim Hikmet was released from prison on the request of the international community, came to the Soviet Union, and lived here until the end of his life. In his book, Prof. Elman Guliev emphasizes that, while talking about his activity, his political convictions, Nazim Hikmet saw the salvation of all humanity in communism, and communism for him was transformed into a religious belief, apart from political beliefs (Guliyev E., 2011: 225). As we have seen, some poetwriters propagandizing this ideology as Nazim Hikmet, Sadri Ertem and others have been sentenced to imprisonment for many times. It should be noted that the Turkish Socialist Party was established in Turkey in the same period and was closed shortly afterwards. The
"Aydınlıg" and "Orag-chakic" press organs, which began to be published in 1921, reflecting the class struggle, have also been persecuted for this ideology.

Researcher M. Chingiz shows that reason for all these was the antiRussian views of the staff that won the War of Liberation. In such a situation, the left-wing literature (socialist-realists) simply had to express their views with poetry and other examples (Chingiz M., 2000: 13). As in the literature of Azerbaijan, in the Turkish literature, the subject of the village and motive of people began to come to the fore. The awakening of the village, struggle for the new life, description of the lifestyle, traditions, ethnographic features and belief system began to be the subject of literature. At the same period,some writers such as Suleyman Rahimov, Mehdi Huseyn, Abulhasan Alekberzade, Bayram Bayramov, Ali Valiyev and others appealed to the topic of the village. It should be noted that at the subsequent stages the subject of village was leading position in the activity of writers such as Movlud Suleymanli, Akram Aylisli and others. However, the topic of the village here was no longer about collective farming, class struggle. 
The relevance of the village theme in Turkish literature, as we have mentioned above, was not only important from the point of view of socialist-realism, but most importantly from the point of view of Ziya Gokalp. Researcher Ahmad Oktay notes that the $1925-1940$ s is a stage in which socialist realism is emerging in Turkey. In these years, the manner of telling is not revolutionary-left, but oriented to nation (Oktay A., 2003: 314). In our view, this is the main point that makes the rural theme different from each other in both literature. Let's look at the examples.

One of the novels that draw attention to this issue is the work of S. Ertem, "When the spinning wheels stopped" (1931), which is a unique place in the Turkish literature. In the novel, the problems such as the village life, the villagers' torments, the economic crisis, unemployment, hunger, getting money with interest, etc. are reflected. Events take place in the second half of the 19th century, in a small village named Adakoy during the Ottoman Empire. The conflict in the work is based on the confrontation between Siddigzade and other major merchants who sell inexpensive fabric imported in Europe, with people who earn a living with weaving in Adakoy and neighboring villages. The only way to earn a living is to spin napped wool and knitting. The villagers live selling the wool to Siddigzade Ali Afandi, the richest man in the village. Therefore, they are trying to create good attitude to Siddigzade. A message from the center comes to Siddigzade. It is written in the letter that wool will be imported from Europe, not from Anatolia. Machines, wheelchairs are stopped. Thus, the villagers' only way of earning is closed. Conflicts in the novel begin to aggravate after this incident. Hasan, one of the main heroes of the work, joins the villagers and goes to the center. Here, the villagers appeal to the government and their complaints are abandoned. Hasan meets with the chief of the textile organization. Let's look at the following dialogue;

"After listening to Hasan, as if an earthquake had passed from his face.

-Everywhere, every side is in such a situation.

This is what happens when you look the machine tool badly... He pulled out his stick between his trembling lips: The state is a hawk, the one wing is army, and the other is worker. Hawk with 
broken a wing cannot fly and it is condemned to crawl...

-But where is the help?

-Help from you, from me, from the all, all of us...

Then he paused for a moment closing his eyes. The chief has left the influence of the man who hid something under his tongue rather than a man who would be able to find remedy for troubles" (Etem S., 1930: 123).

It is evident from the work that the situation is not very different in Istanbul. This fight was not just in Adakoy, but also in all places of hometown. "..The peasants who were at the machines were gathering in large centers in the form of flow. "Proletarization" was spread all over the place as a plague. In Kastamonu, Trabzon, those who fled from the village, sold their goods, burned machine tools, and those who sold factory items opened small shops. That was a terrible chaos. The villages soon became the ruins with the stork slot in their chimneys. These villages were still ownerless. Those who left the village did not return, and most of them became miserable" (Etem S., 1930: 124)...
The writer found the situation of peasant tragic by comparing the poor state of the people who went to the city or those who had no strength to go with the Israeli tribe who were sent to the Babylonian captivity.. If the Israelis saw the spring somewhere, played Tanbur and recalled those days. However, the poor villagers were so weak and hungry that they could not remember the past days. Throughout novel, these boards are reflected in reality. The chief, who lost his previous glory, said to Hasan, "This work can't continue in this form. Death to death, hunger to hunger.. There is no other way! You will kill not to die" (Etem S., 1930: 126). These words inflamed the feelings of the struggle of Hasan. He called villagers to fight:

"They will kill us, or we will kill them. If we established factory by gathering in time, we would oppose their goods with our goods, but it was late. The knife stands on the bone. It is necessary to fight. If you have other ways, say" (Etem S., 1930: 129). Nevertheless, there was a mass of people obeying to the oppression and injustice before Hasan. Moreover, these people only listened to him with tears in their eyes and said, "Do whatever you want, 
do not add us to this issue." The first sparks of struggle appear in the following dialogue:

"Hasan opened this issue again. - Siddigzade and me are mortal. We are here today, not tomorrow. As the world stands, people as Siddigzade and Hasan will always face. The name will probably not to be Siddigzade. .. He can be Yusuf, Kenan, or Ahmed. What is the importance of this? Siddigzade will die, but instead of him another Siddigzade will come" (Etem S., 1930: 30). Thus, the events begin to be complicated. The villagers did not respond to Hasan's struggle, but they slowly began to open their eyes even though they divinify Siddigzade. Siddigzade does not need to give a fake smile to his face, and show his inner face. “...He appears without masking and frightens the people around him with the bareness of all its desires and deeds like complicated, tumorous, wounded body" (Etem S., 1930: 134). Siddigzade's oppression was in the last possible point. On the one hand, machines were closed and people had a terrible hunger. This mass finds remedy in the right of a woman called Dudu Khatun. It should be noted that the writer also touches on religious issues and changes the essence of the work. Dudu Khatunsaw in the dream that she was ordered to build a tomb of $\mathrm{Hz}$. Ali in the place of her house. Thus, the house is transformed into a tomb. Neighbor Asma Sister also spreads among the peasants that Dudu is a delivered "prophetess". Almost as the soul mates, Asma and Dudu Khatun, start to gain confidence as a "prophetess" in the village. The writer speaks of Asma Sister, her dark past, her "prophecy," and then her passion for judgment, and her wrath and anger in the face of obstacles. We see it in the obstacles among charactersas AsmaPazvantoghlu, Asma-Shakir (Salman), Asma-Husein. Writer leads the conflict between lord-peasant, oppressoroppressed, tyrant and humble to the religious-artificial direction. He shows that only Dudu Khatun and Asma Sister can dictate over the crowd, using religion of the people. Thus, all rural population stands up. A great rebellion, the fight begins. They will fight until the last breath. Siddigzade's house is burned at midnight. The rebellionslaid by the army. The main idea in the work is the slogan of Hasan even in the blood, "Comrade, you will kill not to die". 
Let's note, though not so deep, the writer highlights the inner world of characters as Hasan, Asma, Dudu, Khadija and others. In particular, HasanKhadija line draws attention. Although Hasan has been away from the village for a long time, his pure love for Khadija broughthim to this village. While talking to Khadija at the spring, the villagers said that they were "immoral, dishonest" and made them go out of the village. Young people fleeing from the village have been hungry for days and were returning to their homes. When Hasan took her with himself, he saw the trace of deep dagger on her face he was terrified. When Khadija was opposed to Siddigzade to protect her honor, she faced this terrible disaster:

“...The woman was tired. Her face was pale, her lips were white. Whitening lips of Khadija sometimes opened and the groan is heard" (Etem S., 1930: 42) ... "Her body were with thorns and wounds... A wound scar on her face, traces of a deep knife on her left cheek, a trace of kick, and a great hole at the edge of her eye" (Etem S., 1930: 35)...

In the work, Khadija-Hasan line is not romantic love, it is presented in the context of conflict with Siddigzade. As a beloved and loved woman, Khadija draws attention as the peasant who has been abused, exploited not by her emotions and femininity. In his dissertation, researcher Ahmed Demir points out that the real reason for this is to bring Hasan, the hero of the work and Siddigzade ascontradictory force face to face and to give dramatic form lead the event. That is, the character of the Khadija is an image created to bring Hasan and Siddigzade face to face as contradictory poles (Demir A., 2006: 115). The writer shows that the hungry villages are returning and have no choice but to take shelter. When the works are going well, Siddigzade again beats Khadija with violence by getting the opportunity. With the death of Khadija, Hasan's personal feelings turn into public concerns. This revenge is not based on personal malice. This revenge is directed against the tyrants, the oppressors. "When the spinning wheels stopped", as the first socialist-realist novel in Turkish literature, attracted the attention of literary critics. They made interesting comments and judgments about this. O. F. Toprag writes: "The main feature of the work of how the century of factories which caused the economic collapse of 
our country created reactions, how the old age of belief in the Anatolian root system was abandoned (Demir A., 2006: 115). A literary scholar, K. Ertop, C. Gudrat, also emphasizes that local textile production has been defeated before the production of fabrics imported from Europe (Ertop K., 1978: 11-15) (Gudret C., 1999: 30). In the opinion of Ramazan Kaplan, though this work is about domestic production confrontation with foreign production, and the collapse of the economic situation, but the writer has not achieved his purpose so much because of addition of from the ideological point of view, especially because of Sunni-alevi confrontation to the events (Kaplan R., 1997: 79-80). Attila Ilhan emphasizes that work called "When the spinning wheels stopped" reflects the struggle between the people who sold European fabrics and domestic producers in the Ottoman Empire in the 19th century, reducing more than 3000 tools down to 25 , unemployed people, in a word, economic collapse and for this reason, intelligentsia (bureaucracy) in the period of Tanzimat are guilty of:

"After the Tanzimat period, the Ottoman enlightener understood modernity as a 'liberality' whether it was
Turkish or from any other nation. What is liberality, politically free, "open door" policy! Well, your property is not industrialized like the developed western imperialist states, and if their property is too strong to drown your economy in a spoonful of water? Indeed, at that time, "modernity" meant the real "betrayal" (İlhan A., 2001: 12-13).

According to Ramazan Kaplan, this work is important for its ideological look beyond the literary value (Gur A., Engin E., 2015: 605). Having agreed with these thoughts and considerations, it is important to note that the work is primarily the first socialist-realist novel, and in general, when it comes to the landscape, socialist thought in the rural novel after Sadri Ertem (Rashad Enis Aygen, "The Scent of the Land" (Babayeva E., 2018: 17-24), Faik Baysal "Sarduvan" (Babayeva E., 2018: 77-80) , Mahmut Yasari "Woodcock" and so on) exist more strongly. By the way, it should be noted that Nazim Hikmet had a special place in the formation of the idea world of Sadri Ertem. Mustafa Parlak wrote that Nazim Hikmet laid the first groundwork for world of thought of Sadri Ertem in his dissertation entitled "Monographic Work about Sadri 
Ertem", this issue was also quoted in the work of "Blue Eyed Ogre" by Zakariyya Sertel (Parlak M., 1995: 99). It should be emphasized that such issues have become the leitmotif of the writer's stories of "Peasant Who Wears Cylinder Hat", "Honorable Man", "A Woman Who Wasn't Accepted Even By The Valley", “A Man Wearing Ornament Of A Bear" and so on. In these works, problems such as hunger, unemployment, poverty encountered by the villagers are addressed.

One of the works written in this subject and drew attention is "Novel Of The Decade" (1933) by Ethem Izzet Benice (1903-1967). The main heroes of the work are two village children, Erhan and Torun. The young people, who live with Anatolia love, got education in Ankara and returned with great love. In the work, events take place in a remote village of Anatolia during the ten years, in the period of the Balkan Wars and World War I.

Ideology of Kemalism and propaganda of contribution of this ideology to Anatolia are dominant in this work of Benice who is famous for his works such as "The Book to Be Burnt" (1927), "The Maddening Woman"
(1927), "Tears" (1932), and "You Will Love Too" (1942).This ideology is presented in the form of characters of Erhan and Torun. The first parts of the four-part novel are about the miserable situation of the peasant, a lord-peasant, imam-peasant conflict. The writer shows that the Anatolian peasants were ignored during the Ottoman Empire, being persecuted by the masters, the farmhands, the sheikhs. The biggest reasons for this are that the villagers are ignorant, unaware of their rights and freedoms, and on the other hand, their living with the fear of the king and God. Pay attention to the examples;

"This was the village during the period of Ottoman Empire in 1912. Pasha does not love the peasant. Lord does not love the peasant. The Imam does not love the peasant ... The king of the village is Imam. The Sheikh does Godness” (Benice E. İ., 1933: 34). “... Our peasant is ignorant. Hit the peasant and take the bread from them. All of them are in the five daily prayers" (Benice E. İ., 1933: 31).

The writer shows that all of these make the peasant obey and strengthen the hegemony of "aghalig" (supremacy). If we say with the 
expression of the researcher Firat Garagulle, in this work, the reality of "aghalı" is one of the indispensable elements of social identity (Karagulle F., 2015: 87).

On the other hand, the peasant was insulted and beaten violently for driving out the bull entering the field. It proves once again that the peasant is the class of oppressed. The writer expresses hatred and protest against grossness from the tongue of Demir Chavush: "We understood the Imam Efendi. Nobleman is nobleman and farmhand is farmhand. They are both creature. Is it possible to kill somebody for throwing a bull out of the field? Is it forbidden to speak to a bull, not to himself? Do the oxen have to eat seeds of poor people except agha" (Benice E. İ., 1933: 11-12)?

Throughout the work, the Ataturk Revolutions, his ideology, are the subject of great love. The writer expresses his love for Ataturk in the language of heroes, and even gives detailed information in some places. In the final part of the novel, the village with school, the road, all the conditions, well-organized village and hardworking villagers are described. The writer shows that the peasant meets reconstruction of the republic's ideology with great love and joy. Novel ends with the exclamations of peasants: "Long live, Republic".

It should be noted that these works are sometimes matching by Mahdi Husein's novel "Tarlan". There are also two opposing forces in the "Tarlan" as Sadri Ertem's "When The Spinning Wheels Stopped”, Ethem Izzet Benice's "The Novel Of The Decade" as well as the Turkish novels talking about rural life. In the one side, positive characters like Tarlan, Mursal, Khanlar, Hajioghlu, Nadir, Maryam, Aziz, Sadaf and Farman bey, Madad, Shamil, Mahmud and Molla Qasham are in the other side. The main hero of the work is the director of the Ellar village school, Tarlan. The writer describes Tarlan as a very active, hardworking, noble man, who "has not slept in the six years he has been working in the village and has never rested (Huseyn M., 1954: 141)". The writer shows that Tarlan is interested not only in the field of enlightenment in the village, but also in agriculture. Researcher, scientist Yahya Seyidov writes about the character of Tarlan in his work "The Creative Way of Mehdi Husein": "Mehdi Husein describes 
Tarlan with sympathy. It is no coincidence that the writer once again remembers him in "Absheron" and "Black Stones". Tarlan Ismailli is described as a principled, unconquerable and at the same time a sensitive, caring communist" (Seyidov Y., 1966: 47). The writer gives the fullness of the character of Mursal, the head of the collective farm, Sadaf, the young teacher and Hajioghlu as well as Tarlan. The novel reflects socialism, collectivism, collective farming, class struggle, sharp contradictions between contradictory forces. One of the factors that attracts attention is the sharp criticism of religion-superstition. The writer shows that the opposing forces make up the story "Bitdili İmami" ("Imam of mosquito") using the religious belief of the people skilfully to bring them to their side. People used with money can find "healing" in Bitdili (mosquito) pretending themselves as deaf, blind, dumb, or mad among people. Thus, sick people who believe in these frauds come to the Bitdili. The appeal of Tarlan who revealed the false "miracle" to the people, draws particular attention. "Why were you deceived? Because while mullahs are living, the eyes will be closed, the heads will be unconscious, and the ears will be deaf. You came stopping your work. You endured with sleepless nights, what did you earn? Nothing but an insult!.. Forgive me! I do not want to insult those gathering here, especially those making a fuss, you have to know that there is no Imam and he did not heal one person! They deceive you to get your money! Let our enemies be ashamed of their ugly deeds. Where is mullah Gasham, where is Farman bey" (Huseyn M., 1954: 109)? The example we give is, in fact, completely coincides with the lines "The king of the village is the imam. Let Shaikh do Godness" ("Novel Of The Decade"). In general, it is possible for each type of village novel to meet these types of issues. The main reason for this is the fact that ignorance and superstition are in the forefront of class struggle, such as agha-peasant, oppressor-oppressed. Solution of problems attracting attention in the "Tarlan" novel shows itself in the activity of Abulhasan Alekperzade, especially in the novel "Downs". The public novel, "Poems" (1930), consists of three parts. As in the "Tarlan" here, political issues such as class struggle in the village, reconstruction of the village, 
collectivization of agriculture, in other words, the development and the rise of the Soviet village are reflected. The name of the work refers to the difficulty of serious conflicts between novelty and oldness, ups and downs of the inter-class struggle. Yagub Ismayilov pays special attention to the novel "Downs" referring to the role of Abulhasan in the development of the Soviet novel in the 1930s in his monograph "The activity of Abulhasan":

"Abulhasan has created a rich work with interesting plot and composition; has drawn a complex and colourful picture of the collectivization movement in the Azerbaijani village; discovered the essence of events and wishes with the character and fate; brought many live and typical figures to our literature; revealed the power of his mastery, especially the epic cognitive power of life" (İsmayılov Y., 1986: 53).

As it turned out, issues such as collectivization and socialism were one of the typical issues of the novel in the 30's. Works of Mehdi Huseyn, Abulhasan Alekberzade, Suleyman Rahimov, Bayram Bayramov, Ali Valiyev and other writers were the products of this ideology. The most important element of the novel "Novel of Decade" and "Tarlan", as well as "Downs" (Abulhasan) and other Azerbaijani novels, which we have studied for comparative study, was due to the writing of these works in the dictation of the period. Writer Ethem Izzet Benice reflected the concrete phase of the Anatolian village before and after the establishment of the Republic, peasant-lord struggle, and most importantly the reconstruction process in the "Novel Of The Decade". Notable scientist Alemdar Yalchin notes that the novel was written in the excitement of the reconstruction policy initiated during the Republic, emphasizing that the work was strong from the point of the subject, but not as successful as a novel (Yalchin A., 2012: 204). In my opinion, this type of novels, dedicated to Sovietism and class struggle, were written for propaganda of socialism, and today it has almost lost its significance.

\section{Conclusion}

It was Soviet period in Azerbaijan, the Republic period in Turkey in the 1920s and 1930s. During the research, we find that socialist realism from Russian literature 
influences many peoples, as well as Azerbaijani literature, to some extent Turkish literature. Socialist realism was in fact a demand of the regime. Because of socialism in Azerbaijan, novel in the 30 's reflected collective farming, the struggle of workers and peasant classes. Since the Republic was established in Turkey, socialist realism was simply a stream. It could not develop as much as in Azerbaijan. Nevertheless, under the influence of some writers such as Nazim Hikmet, Faik Baisal, Sadri Ertem, Sabahaddin Ali and then Kamal Tahir, Yasar Kamal, Atilla Ilhan, Ilhan Berk, Fakir Baykurt and others in the 50's have written works in this context.

In general, we have concluded that in the 1920s and 1930s, when the Turkish novels were involved in research, we concluded that there was conformity of the Azerbaijani novels in terms of the subject of the village. In both literatures, there were conflicts mostly between contradictory sides and the classes, not between individuals, images in the rural novels. In these novels, the collision reached the highest peak with the lord-peasant, oppressoroppressed, intellectuality and ignorance confrontations, the novel conflict was settled between the lord-peasant, the landowner-hired, the noveltyconservatism, the teacher (intellectual) ignorance, superstition.

For the first time in the article, Azerbaijan and Turkish novels dealing with rural life have been studied comparatively. This is the main scientific innovation of the research.The article can be used in comparative literary criticism, as well as in the study of Turkish and Azerbaijani literature, in the study of activity of Sadri Ertem, Mehdi Husein and Abulhasan Alekberzade.

\section{References}

Akyuz K. (1979). The main features of modern Turkish Literature (1860-1923)

I. Ankara.

Asadullaev S. (1970). Notes On The Novel. Baku.

Atatürk's speeches and statements I. (1945). Ed. Karal E. Z., Istanbul: Turkish Revolution History Institute Publications.

Babayeva E. (2018). Contradictions in rural life in Smell of Earth by Rashad 
Enis Aygan // News of Pedagogical University Series of Humanities, Social and Pedagogical and Psychological Sciences, 66, No 4, p.17-24.

Babayeva E. (2018). Urbanization of Faik Baysal's novel Sarduvan // Ministry of Education of the Republic of Azerbaijan Baku Girls University Scientific Publications, No 3 (35), Baku, p.77-80.

Benice I. (1933). Novel Of The Decade. Istanbul: State Printing House.

Cengiz M. (2000). Socialist Realistic Poem 1923-1953. Istanbul: All The Times Publication.

Demir A. (2006). Social Realism Understanding and Structure. Theme, Expression, Dissertation in Sadri Ertem's Novels and Stories. Dis. ...Ph.D. in Philology, Ankara.

Enveroglu H. (2008). Development Problems Of Azerbaijani Novel. Baku: Nurlan.

Ertop K. (1978). Thirty-fifth Anniversary - From Leading Writers of
Realistic Literature - Sadri Ertem // Milliyet Art Magazine, November 20, pp. 11-15.

Etem S. (1930). When The Spinning Wheels Stopped. Istanbul: Pictorial Moon Printing.

Etem S. (1936). Art and social Issue // Seven-day gazete, No: 168, 27 May.

Gokalp Z. (1970). Principles of Turkicism. Istanbul: State Books of M.E.B.

Guliyev E. (2011). Turkish Nation Literature. Baku: "Conatant empary”.

Gur A., Engin E. (2015). Turkish Literature In The Period Of Republic. Ankara: Akchagh Publications.

Ilhan A. (2001).When Spinning Wheels Stopped. Istanbul: Autopsy Publications.

Ismayilov Y. (1986). Activity of Abulhasan. Baku: Science.

Kaplan R. (1997). Village In The Turkish Novel. Ankara: Akchagh Publications. 
Periódico do Núcleo de Estudos e Pesquisas sobre Gênero e Direito

Centro de Ciências Jurídicas - Universidade Federal da Paraíba V. 8 - No 07 - Ano 2019 - Special Edition ISSN | 2179-7137 | http://periodicos.ufpb.br/ojs2/index.php/ged/index
Karagulle F. (2015). Anatolia Image In The Novel Of Early Republican Period. İstanbul: Bookstore.

Khalilov G. (1973). From The Development History Of The Azerbaijani Novel. Baku: Science publishing house.

Kudret C. (1999). Story and Novel in Turkish Literature 3. Republican Period 1923-1959. Istanbul: Ink1lâp Bookstore. Mehdi Huseyn. (1945). Selected Works, Vol. 1. Baku: Azerneshr.

Okai O. (1980). "A name forgotten at the entrance of the village subject to the Turkish novel: Ahmet Midhat efendi" / First National Turkology Congress, Communiqués. Istanbul: Kervan Publications.

Oktay A. (2003). Sources Of Social Realism. Istanbul: Everest Publications.

Parlak M. (1995). A Monographic Study On Sadri Ertem. Dis. ...Ph.D. in Philology. Erzurum.
Seyidov Y. (1966). The way of activity of Mehdi Huseyn. Baku: Publishing House of Academy of Sciences of Azerbaijan SSR.

Stevick P. (1967). The Theory Of The Novel . New York: The Free Press.

Yalchin A. (2012). Turkish Novel In The Period Of Republic In Terms Of Political And Social Changes 1920-1946. Ankara: Akchagh Publications 